\title{
適用事例を通した交通シミュレーション 利用実態の分析と利用促進への課題
}

\author{
堀口良太 ${ }^{1} \cdot$ 小根山裕之 ${ }^{2}$ \\ ${ }^{1}$ 正会員 博(工) (株)アイ・トランスポート・ラボ（１62-0824 東京都新宿区揚場町2-12-404） \\ ${ }^{2}$ 正会員 工修 東京大学助手 生産技術研究所第5部 (广153-8505 東京都目黒区駒場4-6-1-C504)
}

\begin{abstract}
本論文は，土木学会での「道路利用の情報化・効率化小委員会，評価ツールワーキング」および「交通 シミュレーション実用化促進ワークショップ」において収集した，道路ネットワークシミュレーションモ デルの適用事例を通して，シミュレーション利用実態の現状を分析したものである. 分析に際しては，シ ミュレーションの目的, 対象ネットワークの規模や性質, また入力や評価に用いたデータの質など, 様々 な角度から事例を集計し, 考察を加えている. さらに本論文の最後では, 実務レベルでシミュレーション 利用を促進するための課題と，将来の交通シミュレーションへのニーズを述べている.
\end{abstract}

Key Words: traffic simulation, practical application, gap identification, future requirements.

\section{1.はじめに}

1990 年代以降, 国内外で数多くの動的交通シミ ユレーションモデルの研究開発が活発に報告される ようになり，実務における適用事例も頻繁に報告さ れるようになってきた。しかしながら，一般に入手 できる文献などの資料だけでは，多くのモデルの特 質を把握することは難しい。このため「シミュレー ションはブラックボックス」という批判を免れず, 実務で利用されるツールとしての信頼性を十分に確 立できない状況にあった。

土木学会における道路利用の情報化・効率化小委 員会・評価ツールワーキンググループ(以下 WG5), および交通シミュレーション実用化促進ワークショ ップ(以下 WS)では，これまで verification や validation といった各種のモデル検証手続きを通し てその能力を評価し ${ }^{1)}$, かつそれらの過程を, シミ ユレーションクリアリングハウス ${ }^{2)}$ で公開すること を推奨してきた.これにより，モデル開発者のみな らず利用者，あるいはシミュレーション結果を評価 する第三者が，公正にモデルの適用性を判断できる 情報を得ることができ，シミュレーションモデルに 対する透明性が増すことで，より一層の普及につな がることを期待している.

WG5/WS では，さらにモデルの適用事例を通し てシミュレーションの利用実態を分析し，実務面で の普及を推進する際の課題を明確にすることを試み
た. 同様のシミュレーション利用者に対するアンケ ート調査では，英リーズ大などが中心となって実施 した SMARTEST プロジェクト ${ }^{3)}$ 事例があるが, ミクロシミュレーションに限定して, 利用に際して の問題点を聞くなど，利用者の意識調査という側面 が強い，今回の試みでは，実際にシミュレーション モデルを利用している国内の研究者や実務者の協力 を得て，適用事例シート(付録参照)を収集した。こ のシートには，評価の目的や対象施策だけでなく， 道路ネットワークの設定や交通需要の獲得手段, 現 況再現の評価指標といった，実施状況を示す様々な 項目を記入するようになっており，シミュレーショ ンの利用実態を反映した分析を行うことができた.

事例を収集できたのは, AVENUE ${ }^{4)}$, NETSIM ${ }^{5)}$,

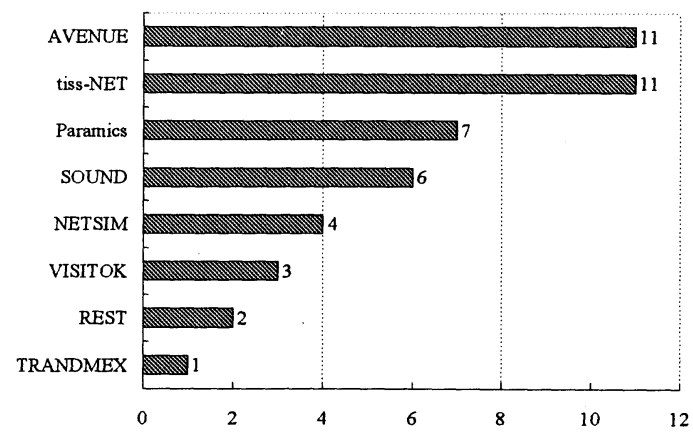

図-1 モデル別の収集事例数 
Paramics $^{6)}$, REST $^{7)}$, SOUND $^{8)}$, tiss-NET ${ }^{9)}$, TRANDMEX $^{10)}$, VISITOK ${ }^{11)}$ の 8 つのモデルで, 合 計 45 事例となった(図-1).

なお，本論文で述ぶる考察は WG5/WS としての 公式な見解ではなく，筆者ら個人のものであること をお断りしておく．また，以降の論旨展開において は，集計結果から判明することだけでなく，筆者ら の経験に基づく考察も含まれる.これがどれくらい の一般性を持つかについては議論があるが，そもそ も本稿はアカデミック視点での分析を主眼とするも のではなく，筆者らを含む実務者の経験から得られ る知見や問題意識を実務者全体で共有し, シミュレ ーション利用の実態や課題を認識することが重要で あると考えているので, ご理解いただきたい.

\section{2. 適用事例の分析}

まず，適用事例の分析に際しての前提を整理して おく．1つ目は，モデル間で適用事例数にばらつき があるが，これは事例シート提供者の業務事情を反 映した結果であることを理解されたい.すなわち， 事例シートは利用者の業務範囲や各業務依頼者への 守秘義務，あるいはデータ入手の難易度などの制約 を考慮して提供されたものであり，必ずしも実際の 業務における適用頻度を示すものではない. 同様の 理由で, 集計結果について統計的な仮説検定などの 分析をすることも適切ではない.したがって，以降 に示す集計結果グラフを考察する際は，事例数の少 ないモデルと多いモデルを対等に扱って，モデルご との性質を議論するのではなく，項目ごとの全モデ ル適用事例数に注目して，シミュレーションの現在 での利用実態を分析している.

2つ目は，対象とする 8 つのデルを便宜上リン

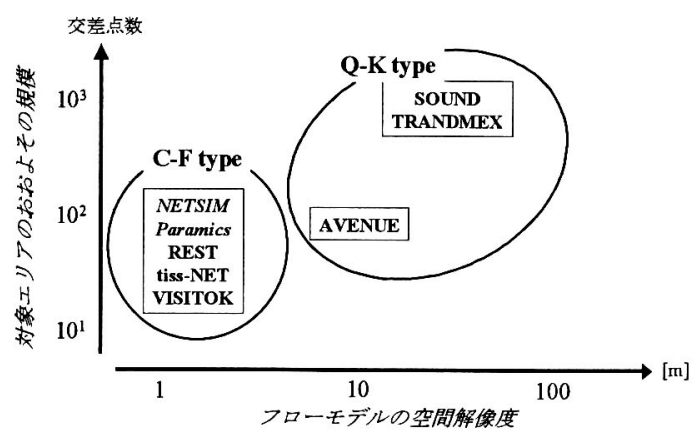

図-2 対象モデルの分類
ク容量などの交通流特性を外生的に与える Q-K 夕 イプと, 追従走行モデルに従って移動する車両の挙 動を集積して交通状態を再現する追従(C-F)タイプ に区別し，それぞれの特性分析を試みていることで ある。

図-2 は各モデルをフローモデルの詳細レベル, すなわち車両がどの程度の時間・空間解像度で特定 できるかを横軸に，それらのモデルが対象とするお およそのネットワーク規模を縦軸にして，タイプご とにグループ化したものである.なお，タイプ区別 の論拠については「交通流シミュレーションの標準

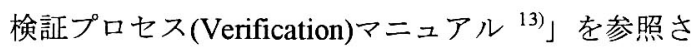
れたい.

以降の集計結果棒グラフでは，各タイプの特性が 見やすくなるよう，Q-K タイプを濃淡の違う塗りつ ぶしで, C-F タイプをハッチングで区別した。同様 に，相関を分析する散布図では，Q-K タイプの事例 をロで, C-Fタイプを○かムでプロットした。

\section{(1) シミュレーションの目的と評価対象施策}

まず，適用事例の目的と評価対象施策を集計し， シミュレーションに対するニーズを分析した(図-3). もっとも多いのは，行政や地方自治体が主体となっ ておこなう渋滞対策プログラムなどを含む「局所渋 滞対策」に分類された事例である.ついで，バス夕 ーミナルなどの交通結節点の整備といった「都市交 通施設整備」，さらに大店立地法で定められる交通 アセスメントなどの「商業施設・イベント対策」,

「ITS・新技術評価」と続く.

この結果から狭いエリアのシミュレーションのニ ーズが大きいことが窅えるが，必ずしもシミュレー ションに対するニーズを必ずしも忠実に反映してい るとは限らない，むしろシミュレーション実施上の 技術的問題やデータ獲得の問題などに起因するシ

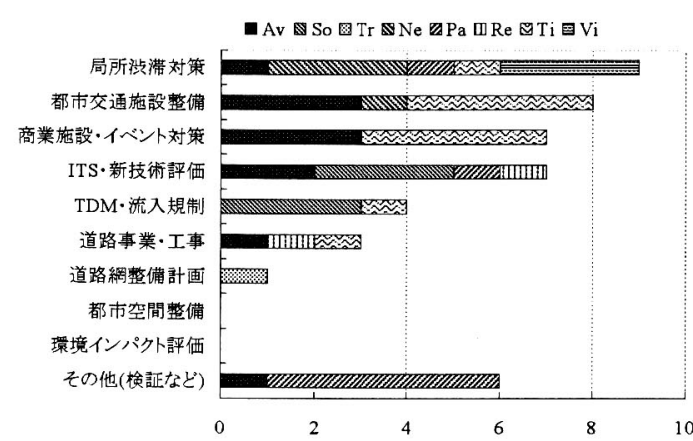

図-3 シミュレーション目的ごとに集計 


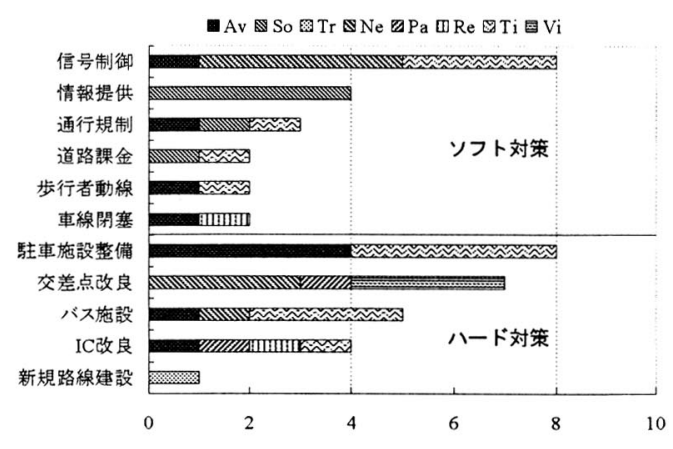

図-4 評価対象施策ごとに集計

ミュレーションの実施しやすさに強く影響された結 果であると考えられる，すなわち，狭いエリアでの シミュレーションは実施しやすいため, シミュレー ションのニーズに応じて適用事例も多くなっている のに対し，広域でのシミュレーションでは実施する 技術的な素地やデー夕の獲得手法が確立されていな いため、ニーズがあっても適用されにくい状況にあ るものと考えられる.

図-4には，それぞれの適用事例で評価対象とな っている施策メニューを分類したものである．交通 運用面でのソフト的な対策と, 施設整備を前提とす るハード的な対策に大別しているが，両者の事例数 はほぼ同じである。

図-3 と図-4 をあわせてみても，Q-K タイプと C$\mathrm{F}$ タイプの利用実態にあまり差違はみられない. 実 際, どちらのタイプであっても, シミュレーション によって評価するものは道路ネットワークのパフォ 一マンス, 寸なわち平均旅行時間や平均速度, 泚滞 長といった集計指標で評価していることが, この後 の分析でも指摘される. 個別車両の動きを計算機上 でシミュレートしている C-F タイプでも, 車両挙動 レベルでの評価指標で議論される事例はなく, 使い 方の面では Q-K タイプと C-F タイプを区別する意 味は, 現状では小さい.

\section{（2）シミュレーションの対象ネットワークおよび時 間帯の設定}

ここでは, シミュレーションの対象エリアを，ネ ットワークの種別と形状によって分類する. 図-5 はネットワークの道路種別ごとに適用事例を集計し たものである.ここで注目すべきは，一般街路が突 出していることよりも，むしろ高速道路と一般道を 組み合わせた統合ネットワークでの適用事例がない ことであろう。

これは統合ネットワークを対象とした場合に自ず と直面する次のような課題が, 適用を阻害している

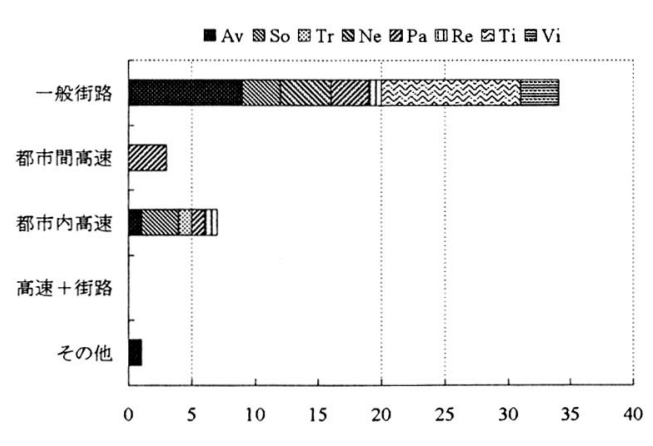

図-5 対象道路種別ごとに集計

と考えられる.

1) 都市圈レベル，あるいは都市間での数 $10 \mathrm{~km}$ 四方に及ぶ広範囲を対象とするため, ネット ワークデータや交通需要, その他の入力デー タを容易に入手できない.

2) 現況再現性を評価するために十分な精度と時 間解像度を備えた交通状況データを得ること が困難である.

3) 高速道路利用の料金抵抗まで考慮した, 利用 者の経路選択モデルを同定することが困難で ある。

筆者らの認識では, 統合ネットワークにおける評 価に対するシミュレーションへの期待は大きいと考 えている，たとえば，近い将来に ETC を積極的に 利用して，高速道路の乗り継ぎを可能にするなどの 柔軟な道路運用，ロードプライシングなどの料金抵 抗を利用した TDM など, 高速道路と一般道の交通 分担をコントロールする施策が現実化すると期待さ れているが，そのためには事前のケーススタディを 動的なシミュレーションで行うことが不可欠である. 上述のような問題を解消する取り組みが強く求めら れる.

また, これらの課題のうち 3)については, 適用事 例をネットワーク形状で集計した結果からも読みと れる(図-6). すなわち, 経路選択の余地があるネッ トワークでの適用数と比べると, 経路選択の余地が ないネットワークでの適用数は倍近くになっている. 事例を詳しくみると, 経路選択の余地がある対象地 域であっても，ネットワーク作成を工夫して経路選 択の必要がないような設定にしているものもある. すなわち，実務においては経路選択に関する複雑な 議論をさけ，シミュレーションを実施しやすい設定 で検討している傾向となっている.

最近のシミュレーションモデルには, 経路選択モ 


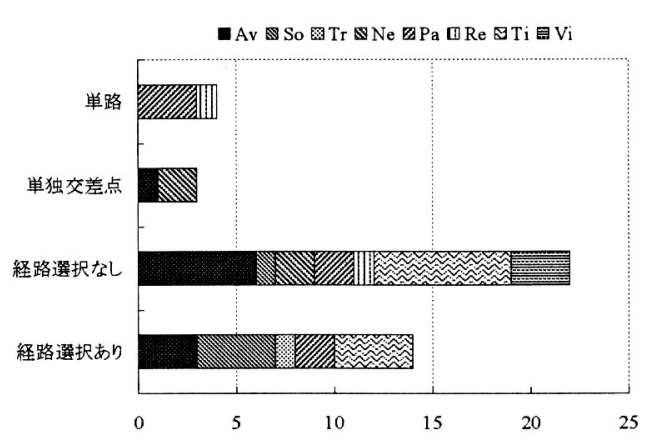

図-6 ネットワーク形状ごとに集計

デルを内包しているものも多いが，その機能を実務 レベルで十分に利用するには，モデルの改良よりも， 低コストでのデー夕獲得や経路選択モデルの同定な ど，シミュレーションを利用するための技術課題一 の取り組みを優先す心゙きである.

また，図-7 は，対象エリアの規模(周囲の長さで 代用)を横軸に，ネットワークでのノード数を縦軸 にプロットしたものである，上側のプロットは全ノ ード，すなわちダミーノードも含めたもので，下側 は信号交差点や合分流点に対応するもののみを計上 したものであるが，ネットワークの規模が大きいほ ど全ノード数と交差点・合分流点数との乘離が大き くなる傾向が読みとれる.

理由の一つに, 交通需要の空間単位との関係が挙 げられる. 大規模なネットワークを対象とする場合， 交通需要は交通センサスなどで利用されるゾーン単 位で設定される場合が多い。このとき，モデルによ ってはゾーンを代表する交通発生集中点(セントロ イド)をネットワークに接続するための便宜的手段 としてダミーリンクやノードを付加する必要がでて くるため，ノード数が多くなると考えられる.

さらに，大規模なネットワークでは寸べての道路 を対象とすることには諸処の制約があり，通常は一 定の条件を満たすリンクのみを抽出して計算を実施 している現状がある．たとえばデジタル道路地図の ようなフルセットの道路データから，対象とする一 部の道路を抽出してネットワークデータを作成した 場合，交差点以外のノードも残されるため，単路状 の道路区間であっても複数のリンクで構成されるこ とになる.このためネットワーク表現がて長となり， ノード数が多くなる.

ゾーンとネットワークをどのようにして接続する か，あるいはネットワーク表現の冗長性をどの程度 許容するか，については一定の基準があるわけでは なく,シミュレーション実施者の判断に寄るところ が大きい。これには次のような問題点が指摘される.
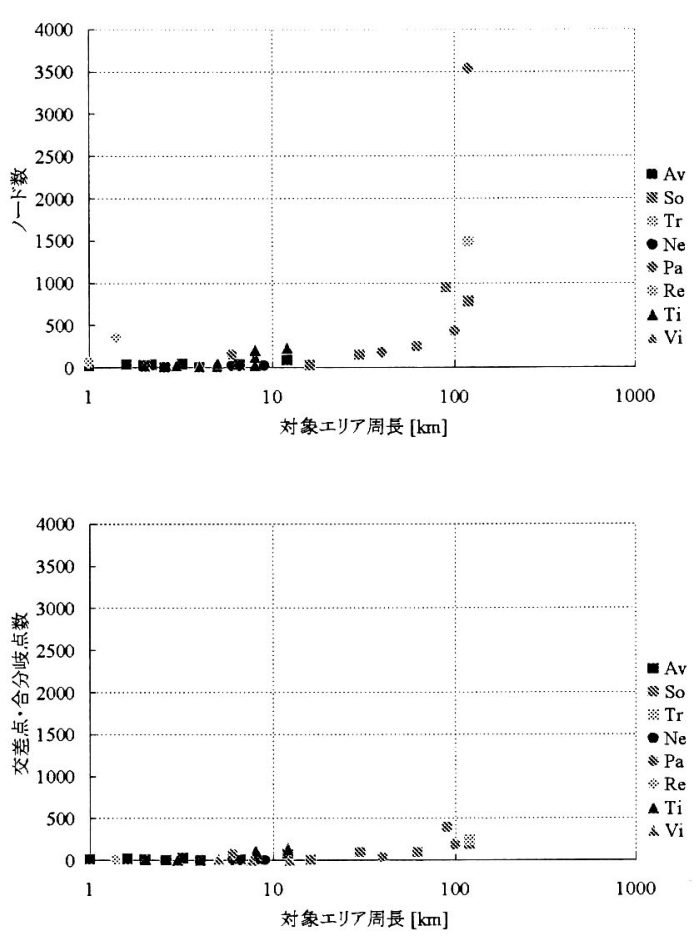

図-7 対象エリア規模とノード数(上)および実際の交差 点・合分岐数 $(下)$ との関係

すなわち，大規模なエリアに対しては Q-K タイ プのモデルが適用される場合が多いが，これらのモ デルはリンクごとに交通特性を与えるため, 同じェ リアを対象としていても，ネットワーク形状が異な ると, シミュレーション結果が異なってしまう。す なわち、シミュレーションを実施する者の資質にシ ミュレーション結果が左右されることとなり，実務 でのシミュレーション利用促進の障害となることが 懸念される.

図-8 では，対象エリア周長と評価対象時間帯幅 の関係を事例ごとにプロットした。対象エリア周長 が $10 \mathrm{~km}$ 程度と比較的狭い場合に, 評価時間帯幅を 1〜4 時間程度となる事例のグループが見分けられ る. ピーク時間帯とその前後 1 時間程度で効果が期 待される渋滞対策を検討する場合は, その影響範囲 をそれほど広くとる必要がないためと考えられる.

一方, 局所エリアを対象としているが, 評価時間 帯幅が 10 時間以上ある事例のグループも確認され る. 内容を見ると, 商業施設のインパクトスタディ がほとんどであり, 対象施設やイベントの稼働時間 によって対象時間帯幅が決まっているものである.

\section{（3）交通需要の設定}

シミュレーションを実施する際, 入カデータとし 


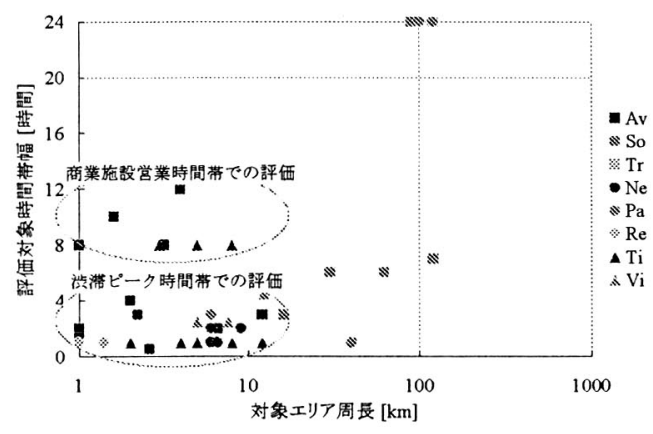

図-8 対象エリア規模と評価時間带幅の関係

て交通需要を設定することが必要である.ここでは， その需要をどのように設定しているかについての分 析を試みる。

図-9 は，交通需要の設定に用いた原データを種 類別に集計したものである. 項目は「その他」をの ぞいて 5 種類あるが，まずモデル仕様に応じて二つ に大別される.すなわち，

1) 経路選択モデルを内包しないシミュレーショ ンモデルに交通需要を設定するため, 交差点 での分岐交通量を入力しているもの. ここで は, NETSIM と VISITOK の適用事例がこれに 当たる.

2) 経路選択モデルを内包するシミュレーション モデルに OD 交通需要を設定するため, 何ら かの手段でデータを作成したもの. 残りの事 例がこれに当たる。

分岐交通量を入力する場合は，一般的な交通量調 査で質のよいデータを入手できるため, 設定は比較 的容易である. しかしながら，ネットワーク形状が 複雑になり, 経路選択の余地が多くなると, 経路が ループするような車両も出てくるため, 適切な分岐 交通量を設定するのは難しい.

一方, OD 交通量を入力する場合は，さらにいく つかの手法が使われている. 最も多いのは, リンク 交通量や交差点方向別交通量, リンク旅行時間から OD 交通量を推定するものである.この場合, 経路 選択を考虑する必要がないネットワークと, 必要が あるネットワークとでは，推定の難易度に差がある。

すなわち, 前者の場合は上流の発生点から下流に 向かって, 交差点方向別交通量から求めた分岐率で 交通量を単純に配分していけば，制約を満たす OD 交通量が容易に得られるが，後者では観測交通量の 制約を満たす OD 交通量が複数存在するため, 既存 のより大きなゾーンレベルの OD 交通量制約やエン

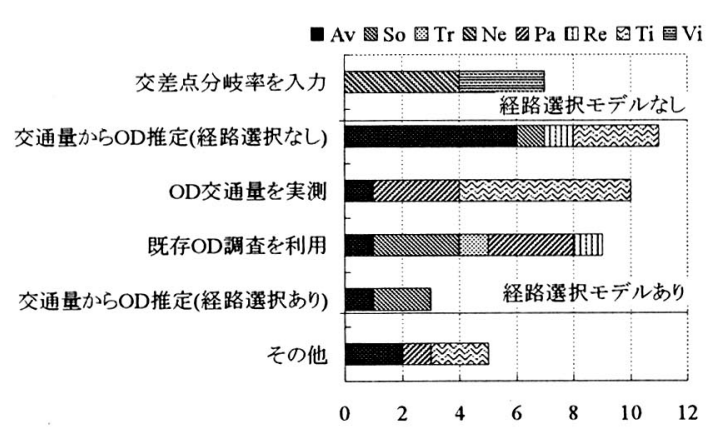

図-9 交通需要設定に用いたデータ種別ごとに集計

トロピー最大化法 ${ }^{13)}$ などの複雑な手法を使って OD 交通量を絞り込む必要がある.このため, 図-6で も指摘されたように, 経路選択を考慮しなくてもす むようなネットワークで検討している事例の方が多 数となっていると考えられる.

いずれにせよ，リンク交通量から OD 交通量を推 定する場合は，ある仮定に基づいて両者が整合させ ているだけなので，それが真の OD 交通量である保 証はない。このため, 特に研究の意味合いが強い適 用事例では, ナンバープレート照合調査を実施して, 対象エリアでの OD 交通量を実測するケース ${ }^{14)}$ も報 告されている.しかしながら，このような照合調査 による OD 交通量観測は, 通常の交通量調査以上に コストがかかるため，実務では一般的ではない．

実務レベルでは，シミュレーションを低コストで 実施することも重要視しなければならないため, 交 通量センサスなどの既存統計調査で求められている OD 交通量をシミュレーションの入力とするケース もみられる.これらの統計量は，公的な機関が公表 しているものなので，上位の制約条件(いわゆる 「お墨付き」)として与えられる場合も多い. しか しながら，現状の交通量センサスにおける起終点調 查のサンプル率は，たかだか 1〜2\%程度といわれて おり，拡大後の精度には疑問の余地があると思われ る. 実際，一般に入手可能なセンサス OD 交通量は, 日単位のものであり, シミュレーションに最低限必 要な時間帯ごとの OD 交通量に分割するには, 慎重 な議論が必要である.

図-10 は各事例で OD 交通量をどの程度の時間単 位で設定しているかを，対象エリアの規模別にプロ ットした図である。いずれのケースでも，60 分を 超えるような間隔で OD を指定した場合はない.ま

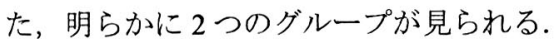

一つは，小規模なエリアで 5〜30 分単位の OD 交 通量を設定しているグループである.これらは, 事 例ごとに何らかの実測調査を実施して OD 交通量を 


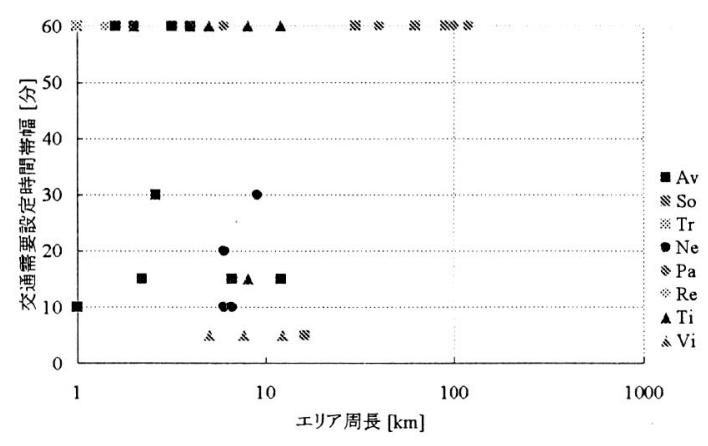

図-10 対象エリア規模と需要設定時間帯幅の関係

設定しているものであるが，現実的に調查が実施で きるエリア規模に制約されているといえる.

もう一つは，エリア規模によらず 1 時間単位での OD 交通量を設定しているグループである.この中 には既存統計調査を利用している事例がほとんどで あるように，利用できるデータの制約によって OD 交通量の時間単位が決まるものである.シミュレー ションでは動的な交通状況を扱うため，はたして 1 時間単位の需要に基づく計算で, 目的とする評価が 十分に行えるのかどうかを，対象エリアや交通現象 の特性を考慮して, 事前に慎重に議論する必要があ る.

\section{（4）シミュレーション結果の評価指標}

最後に，現況再現を実施している事例で，どのよ うな指標を用いているかを分析した(図-11). 最も 多いのは，交通量の再現性のみで評価している事例 である. 諸処の事情から，旅行時間などの別の指標 を調查，あるいは入手することが困難なことが理由 であろうが，これだけでは渋滞によって交通量が少 なくなっているのか, あるいは需要が小さいために 交通量が少なくなっているのか区別ができず，動的 な交通状況の再現性指標としては不十分である.

旅行時間，あるいは渋滞長を評価指標とすれば， 渋滞状況を判別できるが，これらを単独で利用する 場合も不十分である。すなわち，今度は逆に非飽和 領域では, 交通量が増減してもこれらの指標は変化 しないため, 評価が正当になされない問題が残る.

したがって，動的な状況を扱うのであれば，すく なくとも交通量と速度(Q-V)の状態を判別できる 2 つ以上の指標を組み合わせて評価するべきである.

2 つ以上を用いた事例の中では，交通量と旅行時間 による評価を行っているものが多い. 渋滞長で評価 する事例も見られるが，渋滞長の定義が不明確であ ったり，観測が困難であったりするので，精度の面 では交通量と旅行時間を用いるのが適切であろう。

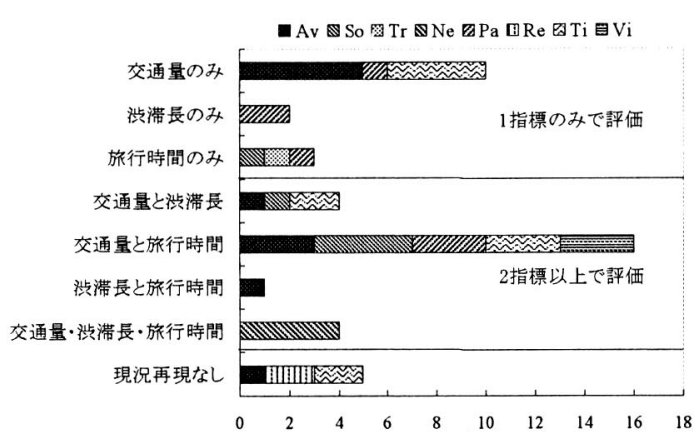

図-11 現況再現性の評価指標ごとに集計

\section{3. シミュレーション利用促進への課題と 将来のニーズ}

以上の分析で明らかになったシミュレーションの 適用実態を踏まえた上で，筆者らの経験に基づく知 見を交えつつ交通シミュレーションモデル利用促進 に対する課題と将来ニーズを次のようにまとめる.

\section{（1）都市レベルでの広域な交通施策を評価する際の ッール利用技術の標準化が求められる}

都市レベルでの適用事例の少なさ(図-3)と，最近 話題にあがることが多いロードプライシングなどに よる TDM 施策や，ITS による動的経路誘導などの 広域施策を評価したいというニーズとのギャップは 明らかである。しかしながら，広域なエリアを対象 とした場合，道路ネットワークデータの作成に手間 がかかる(図-7), 精度のよい OD 交通量の獲得が難 しくコストも大きい(図-9, 図-10)など，実務レべ ルで利用できるデータの制約がシミュレーション利 用を阻害している。このため，公的な機関が動的シ ミュレーションで利用できるデータを収集し，誰で も低コストで使うことができるような仕組みが必要 である.

また，広域シミュレーションではネットワークを どのように設定するかによって，シミュレーション 結果が異なることが懸念される(図-7). 需要が与え られるゾーンとネットワークとの接続方法や, ネッ トワークを構成するリンクの抽出方法について, 標 淮的な基淮を確立することも重要である.

さらに，広域ネットワークでは運転者の経路選択 挙動を扱うことも必須であるが，適切な選択モデル が与えられないことが，その利用を阻害している (図-5，図-6). 街区レベルのシミュレーションであ れば，ネットワーク形状を工夫して経路選択を考慮 
しなくてもすむような設定が可能であるが，広域の 場合はそのようなわけにはいかない，また，本来は 経路選択だけでなく, 出発時間選択, さらにはトリ ップモード選択といった道路交通需要に影響する利
用者行動を考慮することが必要である.これらにつ いては，データを収集する仕組みを作るだけでなく， 需要決定のメカニズムを解明するための研究レベル での取り組みが求められる.

シミュレーションモデル適用事例シート

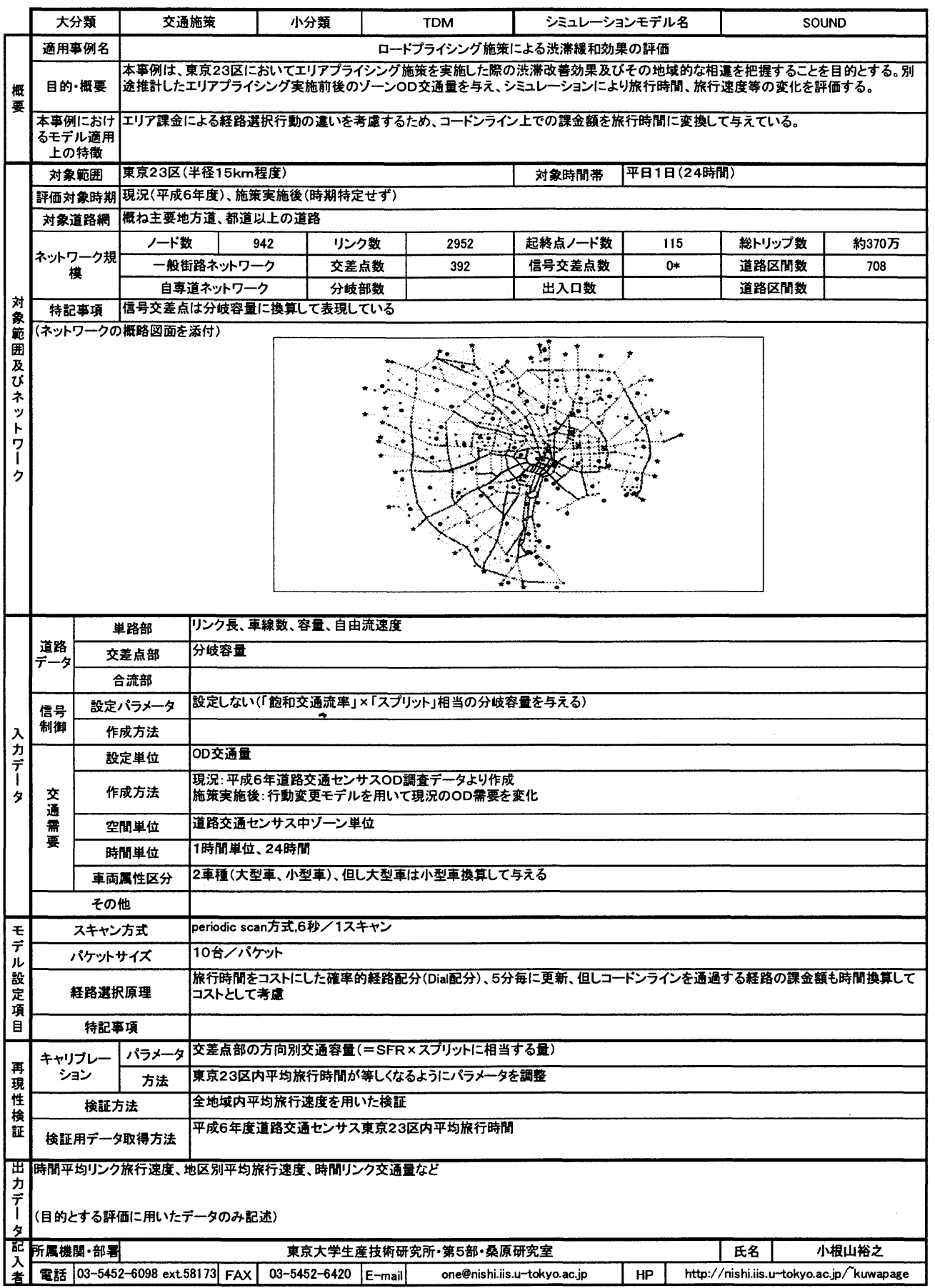

図-12 適用事例シート記入例 
上記のいずれの課題も, シミュレーションモデル の利用の仕方に関わるものである。このため, モデ ルの開発や改良に力を注ぐより，むしろデータ獲得 からケーススタディの設定方法, 結果の解釈の仕方 といった一連の利用の流れを「標準実践マニュア ル」として整備するなどの, 利用技術全般のコーデ イネイトの標準化に重点を置くべきである.

\section{（2）街区レベルでは多岐にわたるニーズに対応す} るサブモデルが求められる

分析では項目を集計するため, 個別事例に特有の 項目をあげることができなかったが，事例シートの 詳細には, 多種多様なシミュレーションへのニーズ が記述されている.これらのニーズによっては，一 般的なネットワークシミュレーションが備える機能 に，その事例ごとの拡張機能を追加することが必要 となる．たとえば，駅前バスターミナルや路上駐車， ETC 料金所などを対象とする場合, それ専用のサ ブモデルを組み込むことになる．モデルのカスタマ イズが柔軟にできることが，シミュレータの大きな 魅力となるだろう.

その際に重要となるのは, 組み込んだサブモデル が新たなブラックボックスとなって, シミュレーシ ヨンの信頼性を損なわないよう, サブモデルごとの 検証を十分に行うことであろう。この場合も，ネッ トワークシミュレーションの検証過程と同様に, 仮 想データを用いてモデル挙動の特性を明らかにする verification 之, 実データを用いてモデルの適用可能 性を評価する validation の 2 つの段階を経ることが 望ましい.

\section{（3）車両挙動レベルでの評価が可能なミクロモデル が求められる}

通説ではミクロモデルと，ここでの C-F モデルは 同義とされているが，適用目的(図-4), 対象施策 (図-4), 対象エリア(図-8), 評価指標(図-11)のいず れを見ても, 使われ方の面では Q-K タイプとの明 確な差は認められない. すなわち, 現状ではいずれ のシミュレーションも, 道路ネットワークの利用効 率を旅行速度や遅れ時間といったマクロ量で評価し ており，その再現性に寄与するボトルネック容量を， 直接パラメータとしてあたえる(Q-K タイプ)か，あ るいは間接的なパラメータで車両挙動を合成して内 生する(C-F タイプ)かだけが, 両者の違いであると いえる.

今後は単に道路利用効率の評価だけにとどまらず， 交通安全施策の評価や, AHS のように車両挙動レ ベルでのサービスを検討したいという, シミュレー
ションへの要求も予想される.このようなニーズに 対応するには, 車両挙動レベルでの再現性が十分に 検証された, 真の意味でのミクロシミュレーション モデルとしての性格と, ネットワークシミュレーシ ヨンとしての性格をバランスよく兼㸚備えたモデル が求められる.

謝辞 : 本論文をまとめるに当たり, WG5/WS およ び(社)交通工学研究会・交通シミュレーション研究 委員会において活発な議論をいただいたメンバー, とりわけ事例シートをご提供いただいた各シミュレ ーションモデル開発者・利用者各位に謝意を表しま す.

\section{付録 適用事例シートの記載例}

図-12 に今回収集した適用事例シートの記載例を 示す. 各事例の内容は文献 ${ }^{15)}$ 参照されたい. な お，今後もシミュレーションクリアリングハウスな どを通して，同様の事例を継続して収集することを 検討している. モデル利用者, 開発者のご協力に期 待するところである.

\section{参考文献}

1) 赤羽弘和, 大口敬, 吉井稔雄, 堀口良太 : 交通シミ ユレーションモデルの実用化に向けての課題，土木 計画学研究講演集, No. 20 (1), pp.521-523, 1997.

2) 道路交通シミュレーションシステムクリアリング八 ウス: http://www.jste.or.jp/sim.

3) Smartest Project: Review of micro-simulation models, http://www.its.leeds.ac.uk/smartest/, 1997.

4) AVENUE: $h$ ttp://www.i-transportlab.jp/products/avenue.

5) CORSIM (NETSIM): http://www.fhwa-tsis.com.

6) Paramics: http://www.paramics.com/.

7) 吉田正, 野呂好幸, 富山礼人：ETC 対応型 IC 計画に 関する基礎的研究一交通流シミュレータ「REST」の， 適用事例の報告, 土木計画学研究・講演集 No.22(2), 1999.

8）吉井稳雄, 桑原雅夫, 森田綽之 : 都市内高速道路に おける過飽和ネットワークシミュレーションモデル の開発，交通工学, Vol.30, No.1, pp.33-41，1995.

9) Sakamoto, K., Kubota, H. and Takahashi, N.: Traffic assignment method considering car-by-car behavior for traffic impact studies -development of the tiss-NET System, Proceedings of 8 th World Conference on Transport 
Research, Antwerpen, 1998.

10) 酒井浩一, 田沢誠也, 吉田克明 : 都市内高速道路シ ミュレーションモデルの開発と検証, 土木学会第 53 回年次学術講演会第 IV 部門論文集, pp. 686-687, 1998.

11) 宇陀正志, 森津秀夫 : 小規模道路網を対象とした交 通シミュレーションモデル, 第 19 回交通工学研究発 表会論文報告集，pp.69-72，2000.

12) Horiguchi, R., Kuwahara, M. and Yoshii, T.: A manual of verification process for road network simulation models an examination in Japan, Proceedings of 7th World

Congress on Intelligent Transport Systems, Torino, 2000.
13) 小根山裕之, 桑原雅夫 : 路側観測交通量からの時間 変化する OD 交通量の推定, 交通工学, Vol. 32, No. 2, pp. 5-16, 1997.

14) 花房比佐友, 吉井稳雄, 堀口良太, 赤羽弘和 : 交通 シミュレーションシステムの再現性検証用データ セットの構築, 土木計画学研究講演集, No. 21 (1), pp.583-586, 1998.

15) 堀口良太 : 検証と適用事例を通したモデル分析, 土 木計画学ワンデーセミナーシリーズ 23 「TTS - 効率的 な道路利用に向けて(2)」, pp.81-137, 2001.

(2001. 6. 11 受付)

\section{FUTURE DIRECTION FOR R\&D ACTIVITIES OF TRAFFIC SIMULATION THROUGH THE ANALYSIS ON PRACTICAL APPLICATIONS IN JAPAN}

\section{Ryota HORIGUCHI and Hiroyuki ONEYAMA}

This research analyzes the present status of the practical use of traffic simulation models in Japan at first. The research also purposes to identify the future direction for research and development activities of traffic simulation. The analysis is subject to 45 summarized reports concerning to the practical applications of eight Japanese/overseas models collected by the simulation working group (WG5/WS) under the technical committee of Japan Society of Civil Engineers. The application reports are aggregated in terms of simulation purposes, subjective policies, network characteristics, data acquisition and evaluation indexes. Finally, the paper concludes the gaps that interfere to promote the practical use of simulation through the analysis, and identifies the future requirements for traffic simulation technology. 